\title{
Before and After the Reform: Fixed Line Internet Penetration in Mexican Households
}

Submitted: $08 / 07 / 2018$

Revised: 04/08/2018

Accepted: 09/08/2018

\author{
María Catalina Ovando Chico* \\ Emmanuel Olivera Pérez** \\ Juan Carlos Bocarando Lara***
}

\begin{abstract}
Purpose - Despite being the second largest mobile market in Latin America regarding subscribers, Mexico's penetration levels remain lower than the regional averages. The aim of this paper is to evaluate whether the Mexican 2013 Telecommunications and Broadcasting Reform helped mitigate or exacerbate the digital divide. In particular, we evaluate if the Reform had an impact on fixed-line internet penetration in Mexico.

Methodology/approach/design - For the assessment, the 2010 Census and 2015 Intercensal Survey data used to create impact indexes through Generalized Linear Models (GLMs) estimations.

Findings - Through a quintile analysis were confronted by results, with the intention of showing the average of internet penetration in each income group. The data obtained suggest that internet penetration had positive variations in all the quintiles indicating that recent regulatory changes in telecommunications matter had helped to reduce the digital divide.
\end{abstract}

Practical implications - The poor and vulnerable groups remain at the digital exclusion; these groups need more digital inclusion actions.

Keywords: Mexico Telecommunications Reform, public policy evaluation, digital divide, ICT4D, digital inclusion.

\section{Introduction}

"Universal digital inclusion policy" is defined at the Mexican Federal Telecommunications and Broadcasting Law as a set of programs and strategies emitted by the Federal Executive committed to providing Information and Communication Technology (ICT) access, including broadband to the whole

\footnotetext{
*Interdisciplinary Center for Graduate Studies and Research, Strategy, Technology \& Society Research Center, Universidad Popular Autonoma del Estado de Puebla (UPAEP). Email: mariacatalina.ovando@upaep.mx

***Interdisciplinary Center for Graduate Studies and Research, Strategy, Technology \& Society Research Center, Universidad Popular Autonoma del Estado de Puebla (UPAEP). Email: emmanuel.olivera@upaep.mx

${ }^{* * *} \mathrm{He}$ has a M.Sc. in Administrative Sciences from the Universidad Veracruzana (UV) in Veracruz-Mexico. He is a full-time Ph.D. student in strategic planning and technology management at the Universidad Autonoma del Estado de Puebla (UPAEP). Email: juancarlos.bocarando@upaep.edu.mx
} 
population, placing special emphasis on the most vulnerable segments of society (CÁMARA DE DIPUTADOS, 2014). Since the Reform, Mexico has done several changes to overcome the facility access barrier; however, the ICT adoption is still low. Despite having increased in recent years, Mexican internet users are only 71.1 million of a 128 million population (INEGI, 2017a). Around 86\% of Mexican internet users are in urban areas; meanwhile, only $14 \%$ are in rural areas. Mexico's great challenge is what some authors call socio-digital gap (RAMÓN; PERAL; ARENAS, 2013).

The digital exclusion is divided into a number of factors such as by differences in skills, culture and other demographics and social variables (FEASEY, 2015; FLAMM; CHAUDHURI, 2007; HILBERT, 2010; VANDEURSEN; VAN-DIJK, 2011). Of the socio-demographic factors, income and education are the strongest predictors of internet purchase (CHAUDHURI; FLAMM; HORRIGAN, 2005). Income is traditionally the most pervasive indicator of development and directly related to internet adoption (HILBERT, 2016; PRIEGER, 2013).

It is worth mentioning in this regard that income distribution in Mexican households is extremely unequal; $10 \%$ of the wealthiest households' income is almost 20 times the amount than of the poorest 10\% (OECD, 2017).

National Survey on Availability and Use of Information Technologies in Households -ENDUTIH, for its acronym in Spanish (INEGI, 2017b)- reported that main determinants for the use of ICT in Mexico are educational level, income, and age of a person. It also was stated that the most backward population are the elderly and the less skilled. Results generated by ENDUTIH and the data presented by CONEVAL (CONEVAL, 2016) in 2016 indicate that poverty is identified as the main reason for technological exclusion.

The high rates of poverty and inequality in access to social services in terms of education, health, housing and culture are the main barriers to the adoption of the Internet in the ICT market in Mexico (CONEVAL, 2017).

Recent studies on the growing digital inclusion literature have reported that the availability of ICT is not centered on the intention to use and adoption of these technologies (TOUDERT, 2013; VAN-DEURSEN; VAN-DIJK, 2014). The focus of the aforementioned intention has been displaced in favor of other interests, such as accessibility and skills. As poverty has proven to be significant factor affecting of digital exclusion worldwide (BARRANTES; GALPERIN, 2008; HILBERT, 2010), but especially in Mexico (CASANUEVA, 2018), this paper used a welfare approach to classify Mexican population in five wealth groups.

The aim of this paper is to evaluate whether the Mexican 2013 Telecommunications and broadcasting Reform helped mitigate or exacerbate the digital divide. For the assessment, the 2010 Census and 2015 Intercensal Survey 
data were used to create impact indexes through Generalized Linear Models estimations (GLMs). Results from 2010 and 2015 were confronted through a quintile analysis, with the intention of showing the average of internet penetration in each income group. The paper first discusses the Telecommunication and Broadcasting Reform, followed by a compilation of the digital inclusion plans of the last 3 presidential terms. Subsequently, the methodology is explained, followed by the results and discussion section and finally, conclusions are set.

\section{The Telecommunications and broadcasting Reform}

On June 11, 2013, the Official Journal of the Federation (DOF for its acronym in Spanish), the institution responsible in Mexico for publishing provisions in various areas of competence issued by the Federation's powers to be observed and applied, announced the Reform to The Magna Carta in the field of telecommunications (the Reform).

The decree establishes that the State will guarantee that services are provided under conditions of competition, quality, plurality, universal coverage, interconnection, convergence, continuity, and without arbitrary interference.

The Reform contained a full set of measures (DE CASTILLA, 2018) such as the establishment of the Federal Telecommunications Institute (IFT for its acronym in Spanish), as the regulatory body for telecommunications; the establishment of telecommunications and broadcasting services as public services of general interest; the creation of specialized courts in telecommunications, broadcasting and economic competition; the figure of preponderance (Significant Market Power), and the imposition of asymmetric regulation, such as price intervention; the growth of foreign investment limits; the construction of a shared public wholesale network.

However, possibly the most relevant issue regarding digital inclusion was the recognition at the constitutional level of the rights to access to ICTs, telecommunications user rights and audiences' rights. The Magna Carta article 6 included a digital inclusion statement: The State will guarantee the population integration to the information and knowledge society, through a universal digital inclusion policy with annual and six-yearly goals (CÁMARA DE DIPUTADOS, 2017). As digital inclusion actions are stated in the constitution, the next section explores the most representative actions in this matter.

\section{Digital Inclusion actions}

Table 1 describes the national digital inclusion plans of the last 18 years, by presidential term. The information was collected from different reports (ASOCIACIÓN DE INTERNET.MX, 2018; OVANDO; OLIVERA, 2018; 
QUINTANILLA, 2016). Unfortunately, there is no information evaluating the impact of each program on internet adoption.

\begin{tabular}{|c|c|c|}
\hline $\begin{array}{c}\text { Presidential } \\
\text { Term }\end{array}$ & Program & Objective \\
\hline \multirow{3}{*}{$\begin{array}{l}\text { Vicente } \\
\text { Fox } \\
\text { Quesada } \\
2000-2006\end{array}$} & $\begin{array}{l}\text { National system } \\
\text { e-Mexico-Digital } \\
\text { Communitary } \\
\text { Centers (DCC). }\end{array}$ & $\begin{array}{l}\text { Support digital inclusion in areas of } \\
\text { difficult access. }\end{array}$ \\
\hline & Enciclomedia & $\begin{array}{l}\text { Bridging the digital divide in the education } \\
\text { sector. }\end{array}$ \\
\hline & RH-net & $\begin{array}{c}\text { Facilitate and implement new mechanisms } \\
\text { for the organization of the Career } \\
\text { Professional Service System (SPC) in } \\
\text { federal offices. }\end{array}$ \\
\hline \multirow{4}{*}{$\begin{array}{l}\text { Felipe } \\
\text { Calderón } \\
\text { Hinojosa } \\
\text { 2007-2012 }\end{array}$} & $\begin{array}{c}\text { National } \\
\text { Broadband } \\
\text { Impulse Network } \\
\text { (NIBA Network) }\end{array}$ & $\begin{array}{c}\text { Deploy a backbone fiber network to offer } \\
\text { connectivity services to institutional actors } \\
\text { in the country. }\end{array}$ \\
\hline & Impulse to CCD & $\begin{array}{c}\text { Connectivity was provided to } 14,566 \\
\text { CCDs to cover the lack of internet services } \\
\text { in remote areas. }\end{array}$ \\
\hline & $\begin{array}{l}\text { Digital Skills for } \\
\text { All Program } \\
\text { (PHDT) }\end{array}$ & $\begin{array}{l}\text { The PHDT platform included the use of } \\
\text { Telematic Classrooms, which sought to } \\
\text { integrate the Enciclomedia equipment with } \\
\text { an educational content management } \\
\text { system, a local portal administration } \\
\text { system, but above all with a high capacity } \\
\text { Internet connection. }\end{array}$ \\
\hline & $\begin{array}{l}\text { CompuApoyo } \\
\text { Program }\end{array}$ & $\begin{array}{l}\text { Workers of affiliated companies received } \\
\text { support from the government for the } \\
\text { acquisition of a computer equipment. To } \\
\text { supplement the program, } \$ 500 \mathrm{MXN} \\
\text { support was granted for Internet } \\
\text { subscription. }\end{array}$ \\
\hline \multirow[t]{2}{*}{$\begin{array}{c}\text { Enrique } \\
\text { Peña Nieto } \\
2013-2018\end{array}$} & $\begin{array}{l}\text { México } \\
\text { Conectado }\end{array}$ & $\begin{array}{l}\text { It seeks to guarantee the constitutional } \\
\text { right of access to broadband Internet, } \\
\text { through the deployment of } \\
\text { telecommunications networks that provide } \\
\text { connectivity in public places and spaces in } \\
\text { the three areas of government: federal, } \\
\text { state and municipal. }\end{array}$ \\
\hline & $\begin{array}{l}\text { Digital Inclusion } \\
\text { Program (PID) }\end{array}$ & $\begin{array}{l}\text { Develop digital skills and computational } \\
\text { thinking for student learning, provides } \\
\text { access to broadband Internet, digital } \\
\text { resources and equipment to selected public } \\
\text { schools. }\end{array}$ \\
\hline
\end{tabular}




\begin{tabular}{|c|c|c|}
\hline $\begin{array}{c}\text { Presidential } \\
\text { Term }\end{array}$ & Program & Objective \\
\hline \multirow{2}{*}{$\begin{array}{c}\text { Enrique } \\
\text { Peñ Nieto } \\
(2013-\end{array}$} & $\begin{array}{c}\text { Program for the } \\
\text { Development of } \\
\text { the Software } \\
\text { Industry and } \\
\text { innovation } \\
\text { (PROSOFT) }\end{array}$ & $\begin{array}{c}\text { Promote productivity in strategic sectors of } \\
\text { the country through the adoption of ICT } \\
\text { and innovation. }\end{array}$ \\
\cline { 2 - 3 } & $\begin{array}{c}\text { National } \\
\text { Wholesale } \\
\text { Network }\end{array}$ & $\begin{array}{c}\text { Optimize the use of the 700 MHz } \\
\text { frequency band, reduce costs and increase } \\
\text { coverage in regions without broadband } \\
\text { services. }\end{array}$ \\
\hline
\end{tabular}

Table 1 - 2000-2018 Digital inclusion plans

In addition to the digital inclusion stimulus programs, maybe the most relevant supply side measure proposed by the regulator was preponderant agent's control price. However, unlike communications price index and mobile price index, the fixed broadband price index has not changed much. In January 2013 it had a value of 99.78, while in June 2018 a value of 101,082 was reported (IFT, 2017). The current basic (10 Mbps) fixed broadband plan (august 2018) was provided by the preponderant for a price of $\$ 349$ Mexican pesos per month, approximately \$19 USD. This amount represents $13.36 \%$ of the monthly minimum wage, meanwhile the latest statistic survey reported that only $4 \%$ of family income is earmarked for communication expenses (INEGI, 2016).

\section{Methodology}

The aim of the paper is to evaluate whether the Mexican 2013 Telecommunications and broadcasting Reform helped mitigate or exacerbate the digital divide. For the assessment, the 2010 Census and 2015 Intercensal Survey data were used to create impact indexes through Generalized Linear Models estimations (GLMs). Figure 1 shows the general framework of the study.

\begin{tabular}{|l|r|r|}
\hline \begin{tabular}{|l|} 
2010 Population and \\
Household Census \\
$\mathrm{n}=2.9$ million
\end{tabular} & $\begin{array}{c}\text { 2015 Intercensal } \\
\text { Survey } \\
\mathrm{n}=5.8 \text { million }\end{array}$ \\
\hline \begin{tabular}{|l|} 
Qualitative variables \\
- Type of households, electricity availability, availability \\
of drinking water, sewer system, Internet and ICT \\
Devices: computer, telephone, cell phone, and Internet. \\
Quantitative variable \\
- Income households.
\end{tabular} & $\begin{array}{c}\text { Analysis by } \\
\text { quintiles }\end{array}$ \\
\hline
\end{tabular}

Figure 1 - General framework of the study 
The research framework includes data from two statistical reports published by Instituto Nacional de Estadística y Geografía (INEGI for its acronym in Spanish). The first one is the 2010 Population and Household Census (INEGI, 2010) and the second is the 2015 Intercensal Survey (INEGI, 2015); both statistical surveys were based on probability samples.

The database, constructed for analysis purposes, contains microdata on eleven variables related to household conditions by geographic unit: type of dwelling (e.g. detached house, mobile house, apartment; etc.), service availability (electricity, drinking water, sewer system, computer, telephone, cell phone and internet) and household income.

For the assessment, an analysis based on the Gaussian Distribution and the method Generalized Linear Model (GLMs for its acronym in English) was used. The GLMs are based on the family of exponential linear functions, which include Normal and Reverse Normal distributions, Poisson, Negative Binomial, Bernoulli (Probit and Logit) and Gamma. Given the form of the functions, the estimates of the models are based on Maximum-Likelihood procedures.

Essentially GLMs are a generalization of Ordinary Least Squares (OLS), assuming more complex distributions that contribute to a better fit with a nonlinear estimate with homoscedastic errors (MCCULLAGH, 1984; NELDER, 1977). The function that defines the GLM with the given estimator $\theta$ is:

$$
Q(\theta)=\sum_{i=1}^{N}\left[a\left(m\left(X_{i}, B\right)\right)+b\left(Y_{i}\right)+c\left(m\left(X_{i}, B\right)\right)\right]
$$

Where there is the conditional mean of $y, a($.$) and c($.$) are the members of$ the families of exponential linear functions and $b($.$) is a normalized constant. The$ Maximum-Likelihood estimation is to find the derivative that optimizes the exponential linear function for each $\mathrm{X}$ and thus determine the estimates of the model. In this sense, the estimators are consistent and efficient at the correctly specified conditional mean.

In cases in which the variance function is unknown, it is always possible to estimate the variance-covariance Matrix of the estimators with robust standard errors. Descriptive statistics of the variables used for the 2010 and 2015 analysis are described in Table 2 and Table 3, respectively. 


\begin{tabular}{|l|c|r|r|c|c|}
\hline \multicolumn{1}{|c|}{ Variable } & \multicolumn{1}{c|}{ Obs } & \multicolumn{1}{c|}{ Mean } & Std. Dev. & Min & Max \\
\hline State & $2,903,640$ & 17.95129 & 7.86225 & 1 & 32 \\
\hline Municipal levels & $2,903,640$ & 81.89604 & 107.5908 & 1 & 570 \\
\hline Type of dwelling & $2,903,640$ & 1.09896 & 0.70309 & 1 & 9 \\
\hline Electricity availability & $2,885,227$ & 0.954559 & 0.20827 & 0 & 1 \\
\hline $\begin{array}{l}\text { Availability of drinking } \\
\text { water }\end{array}$ & $2,626,692$ & 0.498773 & 0.499999 & 0 & 1 \\
\hline Sewer system and ICT & $2,874,519$ & 0.505125 & 0.499974 & 0 & 1 \\
\hline $\begin{array}{l}\text { Internet ande: computer } \\
\text { Device: }\end{array}$ & $2,882,847$ & 0.172374 & 0.377705 & 0 & 1 \\
\hline $\begin{array}{l}\text { Internet and ICT } \\
\text { Device: telefone }\end{array}$ & $2,882,380$ & 0.289679 & 0.453614 & 0 & 1 \\
\hline $\begin{array}{l}\text { Internet and ICT } \\
\text { Device: cell phone }\end{array}$ & $2,883,058$ & 0.467046 & 0.498913 & 0 & 1 \\
\hline $\begin{array}{l}\text { Internet and ICT } \\
\text { Device: internet }\end{array}$ & $2,882,004$ & 0.112451 & 0.315921 & 0 & 1 \\
\hline Household income & $2,310,550$ & 6380.41 & 12947.82 & 0 & 999998 \\
\hline
\end{tabular}

Table 2 - 2010 Descriptive statistics

\begin{tabular}{|c|c|c|c|c|c|}
\hline Variable & Obs & Mean & Std. Dev. & Min & Max \\
\hline State & $5,854,392$ & 17.84108 & 7.978077 & 0 & 32 \\
\hline Municipal levels & $5,854,392$ & 73.98461 & 96.97825 & 0 & 570 \\
\hline Type of dwelling & $5,854,392$ & 2.854398 & 12.24134 & 0 & 99 \\
\hline Electricity availability & $5,826,321$ & 0.976644 & 0.151031 & 0 & 1 \\
\hline $\begin{array}{l}\text { Availability of drinking } \\
\text { water }\end{array}$ & $5,514,675$ & 0.53137 & 0.499015 & 0 & 1 \\
\hline Sewer system & $5,805,232$ & 0.573734 & 0.494534 & 0 & 1 \\
\hline $\begin{array}{ll}\text { Internet and } & \text { ICT } \\
\text { Device: computer } & \\
\end{array}$ & $5,813,807$ & 0.200574 & 0.40043 & 0 & 1 \\
\hline $\begin{array}{l}\text { Internet and ICT } \\
\text { Device: telephone }\end{array}$ & $5,812,499$ & 0.242586 & 0.428647 & 0 & 1 \\
\hline $\begin{array}{l}\text { Internet and ICT } \\
\text { Device: cell phone }\end{array}$ & $5,814,455$ & 0.662042 & 0.473014 & 0 & 1 \\
\hline $\begin{array}{lcc}\text { Internet and } & \text { ICT } \\
\text { Device: internet } & \\
\end{array}$ & $5,811,062$ & 0.185564 & 0.388755 & 0 & 1 \\
\hline Household income & $4,284,584$ & 7527.837 & 12833.16 & 0 & 999998 \\
\hline
\end{tabular}

Table 3 - 2015 Descriptive statistics

\section{Results and discussion}

After the creation of the five wealth groups by the aforementioned method, we confirmed that Mexico is characterized by a significantly unequal distribution 
of household income, as the Consejo Nacional de Evaluación de la Política de Desarrollo Social (CONEVAL for its acronym in Spanish) reported (CONEVAL, 2016). Table 4 shows the average household income distribution for 2010 and 2015 by quintile.

\begin{tabular}{|c|r|r|r|c|}
\hline Quintile & \multicolumn{1}{|c|}{$2010 \mathrm{~min}$} & $2010 \max$ & $2015 \min$ & $2015 \max$ \\
\hline 1 & 0 & 857 & 0 & 2143 \\
\hline 2 & 858 & 3000 & 2144 & 4200 \\
\hline 3 & 3001 & 5143 & 4201 & 6429 \\
\hline 4 & 5144 & 9000 & 6430 & 10501 \\
\hline 5 & 9001 & 999998 & 10503 & 999998 \\
\hline
\end{tabular}

Table 4 - Household income per quintile in MXN

Table 4 also evidence that 2010 quintile 1 is entirely below the extreme poverty line as the basic monthly basket of goods per person was $970 \mathrm{MXN}$ in that year. It is worth to highlight that most of the population in quintiles 1 and 2 in both 2010 and 2015 study year, are below the welfare line as it was established at 2,107 and 2,615 MXN per person respectively (CONEVAL, 2016).

This information is consistent with the fact that in that 2010, 13 million inhabitants (11.3\% of the population) lived in extreme poverty and $46.1 \%$ (52.8 million inhabitants) lived in poverty (CONEVAL, 2017). As a consequence of this situation, it seems unlikely that a person of this quintile could afford $4.4 \%$ of its income on communications, which is the 2016 average spending (INEGI, 2016).

To analyze the effects of the 2013 Telecommunications Reform on internet adoption, two adoption indexes were constructed, for the years 2010 and 2015 as shown in Table 5.

\begin{tabular}{|c|c|c|}
\hline Year & 2010 & 2015 \\
\hline \multirow{2}{*}{ Income } & 0.000 & 0.000 \\
\hline & $(198.84)^{* * *}$ & $(220.82)^{* *}$ \\
\hline \multirow{2}{*}{$\mathrm{C} 1$} & 0.119 & 0.168 \\
\hline & $(958.51)^{* *}$ & $(1,499.54)^{* *}$ \\
\hline \multirow{2}{*}{ Cons } & 0.104 & 0.173 \\
\hline & $(493.31)^{* *}$ & $(933.29)^{* *}$ \\
\hline \multirow{2}{*}{$\mathrm{N}$} & $2,087,401$ & $4,060,982$ \\
\hline & $\mathrm{p}<0.05 ; * *$ & $\mathrm{p}<0.05 ; * * \quad \mathrm{p}<0.01$ \\
\hline
\end{tabular}

Table 5 - Generalized Linear Model 


\begin{tabular}{|c|r|r|c|}
\hline $\begin{array}{c}\text { Quintile by } \\
\text { Household }\end{array}$ & No & \multicolumn{1}{c|}{ Yes } & Total \\
\hline 1 & 99.89 & 0.11 & 100.00 \\
\hline 2 & 99.72 & 0.28 & 100.00 \\
\hline 3 & 99.01 & 0.99 & 100.00 \\
\hline 4 & 96.16 & 3.84 & 100.00 \\
\hline 5 & 38.54 & 61.46 & 100.00 \\
\hline Total & 86.67 & 13.33 & 100.00 \\
\hline
\end{tabular}

Table 6 - Year 2010 Household with Internet Access (\%)

\begin{tabular}{|c|r|r|c|}
\hline $\begin{array}{c}\text { Quintile by } \\
\text { Household }\end{array}$ & No & \multicolumn{1}{c|}{ Yes } & Total \\
\hline 1 & 98.85 & 1.15 & 100.00 \\
\hline 2 & 97.49 & 2.51 & 100.00 \\
\hline 3 & 93.40 & 6.60 & 100.00 \\
\hline 4 & 76.86 & 23.14 & 100.00 \\
\hline 5 & 22.67 & 77.33 & 100.00 \\
\hline Total & 77.89 & 22.11 & 100.00 \\
\hline
\end{tabular}

Table 6 - Year 2015 Household with Internet Access (\%)

Table 6 and Table 7 show the percentage of households that adopt or do not adopt internet in each quintile for the year 2010 and 2015 respectively. It can be observed that there is an adoption increment in all quintiles, as there was a general increment of $165.9 \%$. The results seem to suggest that the Reform was responsible for the increase in adoption. However, recent findings suggested that the adoption trend plays a significant role (OVANDO; OLIVERA, 2018). In relative terms, quintile 1 had the biggest increment $(1045.5 \%)$, followed by quintile 2 (896.4\%).

Quintiles 3 and 4 had also a huge increase (666.7\% and 602.6\%, respectively), while quintile 5 only reached an increment of $125.8 \%$. As internet penetration levels were extremely low in 2010's first quintile, it is no wonder that the biggest increments were on the aforementioned group. However, in absolute terms, results adoption shows a direct relationship with wealth, as Quintiles 1 o 3 hold below $10 \%$ adoption levels.

Charts 1 and 2 shows the relation between the 2010 and 2015 adoption index and household income. 2010 graph shows a greater concentration on the origin, implying that most of the households, and especially the ones with lower income, had not adopted internet, while 2015 graph shows more dispersion. 


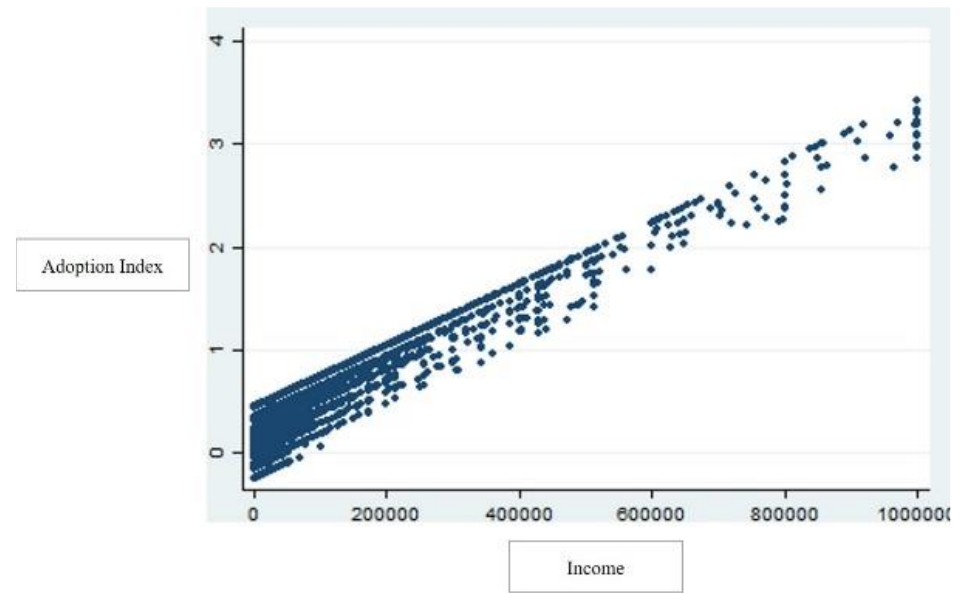

Chart 1 - 2010 Adoption Index by Income

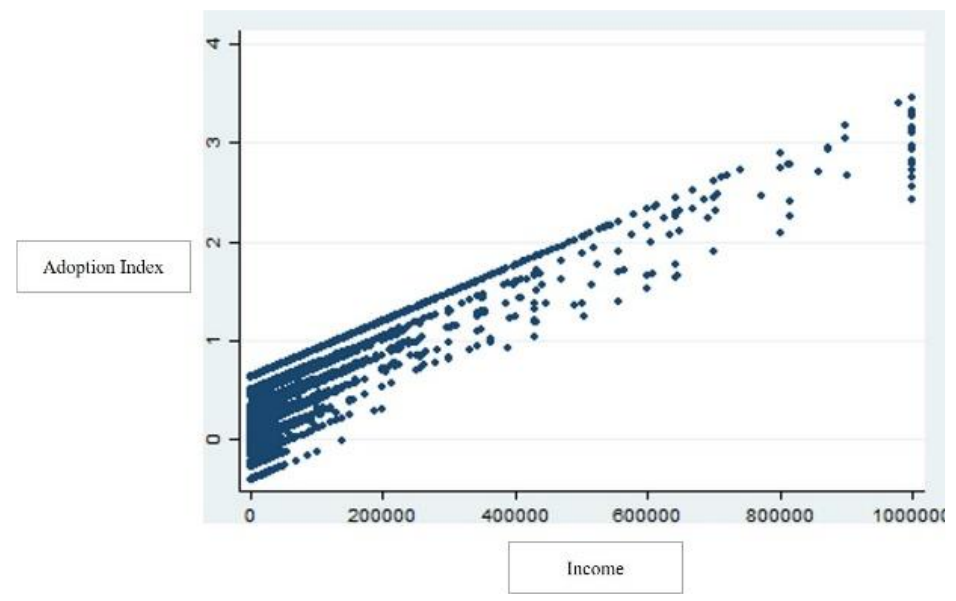

Chart 2 - 2015 Adoption Index by Income

From a general point of view, it is important to mention that in the mean adoption index grew; the index went from being 0.1036215 to 0.1631014 respectively. Chart 3 shows the relation between the 2010 and 2015 adoption index. 


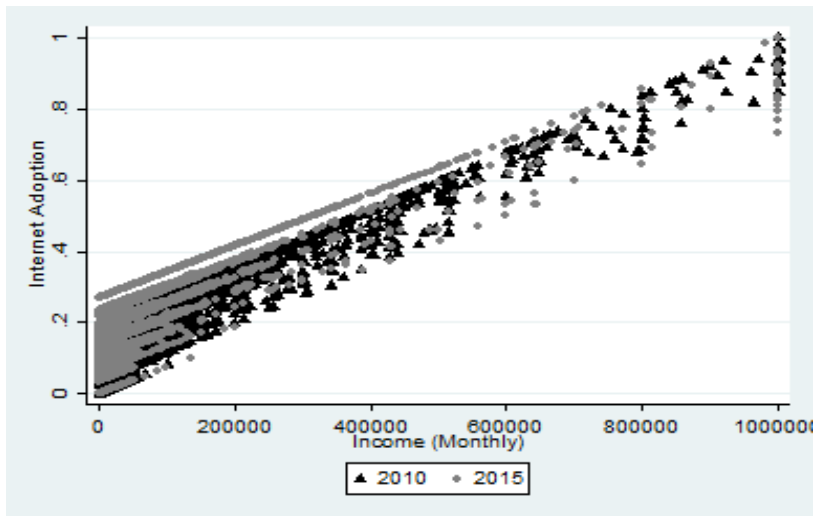

Chart 3 - 2010 and 2015 Adoption Index

\section{Conclusion}

The aim of this paper evaluated whether the Mexican 2013 Telecommunications and broadcasting Reform helped mitigate or exacerbate the digital divide. For the assessment, the 2010 Census and 2015 Intercensal Survey data used to create impact indexes through GLMs estimations. Through a quintile analysis were confronted by results, with the intention of showing the average of internet penetration in each income group.

The data obtained suggests that between 2010 and 2015, internet penetration had positive variations in all the quintiles and $57 \%$ overall, indicating that recent regulatory changes in telecommunications matter had helped to reduce the digital divide. However, the impact was not homogeneous in all the quintiles. Internet penetration increment was more significant in the lower quintiles (those with lower income) and positive, but less important in the first quintile (those with higher income).

However, in absolute terms, quintiles 1 to 3 hold adoption levels below $10 \%$. In addition, it was found that the first quintile's average household income was below the basic basket of goods line. As a direct consequence of this situation, it seems unlikely that a person of this quintile could afford an internet subscription.

Finally, it can be concluded that the Reform helped to reduce the digital divide but not in homogenous way; more digital inclusion actions will be needed especially for the poorest. 


\section{References}

ASOCIACIÓN DE INTERNET.MX. Estudio de inversiones gubernamentales en Tecnologías de la Información y de la Comunicación. Disponível em: <https://www.asociaciondeinternet.mx/es/>. Acesso em: 8 abr. 2018.

BARRANTES, R.; GALPERIN, H. Can the poor afford mobile telephony? Evidence from Latin America. Telecommunications Policy, v. 32, n. 8, p. 521-530, set. 2008.

CÁMARA DE DIPUTADOS. Ley Federal de Telecomunicaciones y Radiodifusión.

<http://www.diputados.gob.mx/LeyesBiblio/pdf/LFTR_150618.pdf>.

Acesso em: 6 maio. 2018.

CÁMARA DE DIPUTADOS. Constitución Política de los Estados Unidos Mexicanos. Disponível em: <http://www.diputados.gob.mx/LeyesBiblio/pdf/1_150917.pdf>. Acesso em: 5 mar. 2018.

CASANUEVA, C. Telecomunicaciones, servicio universal y pobreza en México: hacia una evaluación de una política pública: 1990-2013. In: Las Telecomunicaciones en México: Regulación y Reforma Competencia, Desarrollo de Infraestructura e Inclusión Digital (1990-2017). Ciudad de México: Porrúa, 2018. p. 51.

CHAUDHURI, A.; FLAMM, K. S.; HORRIGAN, J. An analysis of the determinants of internet access. Telecommunications Policy. Anais...Pergamon, out. 2005

CONEVAL. Evolución de las líneas de bienestar y de la canasta alimentaria. Disponível em: <http://www.coneval.org.mx/Medicion/MP/Paginas/Lineas-de-bienestary-canasta-basica.aspx>. Acesso em: 3 fev. 2018.

CONEVAL. Coneval Informa La Evolución de la Pobreza 2010-2016. Disponível <https://www.coneval.org.mx/SalaPrensa/Comunicadosprensa/Document s/Comunicado-09-Medicion-pobreza-2016.pdf>. Acesso em: 4 mar. 2018.

DE CASTILLA, C. Telecomunicaciones y radiodifusión en MéxicoMéxicoUNAM, , 2018.

FEASEY, R. Confusion, denial and anger: The response of the telecommunications industry to the challenge of the Internet. Telecommunications Policy, v. 39, n. 6, p. 444-449, 2015.

FLAMM, K.; CHAUDHURI, A. An analysis of the determinants of broadband access. Telecommunications Policy, v. 31, n. 6-7, p. 312-326, 2007. 
HILBERT, M. When is cheap, cheap enough to bridge the digital divide? Modeling income related structural challenges of technology diffusion in Latin America. World Development, v. 38, n. 5, p. 756-770, 2010.

HILBERT, M. The bad news is that the digital access divide is here to stay: Domestically installed bandwidths among 172 countries for 1986-2014. Telecommunications Policy, v. 40, n. 6, p. 567-581, jun. 2016.

IFT. Reportes estadísticos. Disponível em: <https://bit.ift.org.mx/BitWebApp/>. Acesso em: 7 ago. 2018.

INEGI. Censo de Población y Vivienda 2010. Disponível em: <http://www.beta.inegi.org.mx/proyectos/ccpv/2010/>. Acesso em: 19 mar. 2019.

INEGI. Encuesta Intercensal 2015. Disponível em: <http://www.beta.inegi.org.mx/proyectos/enchogares/especiales/intercens al/>. Acesso em: 19 mar. 2019.

INEGI. Encuesta Nacional de Ingresos y Gastos de los Hogares (ENIGH) 2016. <http://www.beta.inegi.org.mx/proyectos/enchogares/regulares/enigh/nc/ 2016/default.html>. Acesso em: 2 fev. 2018.

INEGI. Comunicado de prensa núm. 122/17: aumentan uso de internet, teléfonos inteligentes $\mathbf{y}$ tv digital. Disponível em: <http://www.inegi.org.mx/saladeprensa/boletines/2017/especiales/especi ales2017_03_02.pdf>. Acesso em: 1 fev. 2018a.

INEGI. Encuesta Nacional sobre Disponibilidad y Uso de las Tecnologías de la Información en los Hogares 2016. Disponível em: <http://www.beta.inegi.org.mx/proyectos/enchogares/regulares/dutih/201 7/>. Acesso em: 2 mar. 2018b.

MCCULLAGH, P. Generalized linear models. European Journal of Operational Research, v. 16, n. 3, p. 285-292, 1984.

NELDER, J. A. A reformulation of linear models. Journal of the Royal Statistical Society. Series A (General), p. 48-77, 1977.

OECD. Estudios Económicos de la OCDE. Disponível em: <https://www.oecd.org/eco/surveys/mexico-2017-OECD-Estudioseconomicos-de-la-ocde-vision-general.pdf > . Acesso em: 1 abr. 2018.

OVANDO, C.; OLIVERA, E. Was household internet adoption driven by the reform? Evaluation of the 2013 telecommunication reform in Mexico. Telecommunications Policy, 2018.

PRIEGER, J. E. The broadband digital divide and the economic benefits of mobile broadband for rural areas. Telecommunications Policy, v. 37, n. 6-7, p. 
483-502, 2013.

QUINTANILLA, G. Política informática en México: Desarrollo, lecciones y avances. Espacios Públicos, v. 19, n. 45, 2016.

RAMÓN, M.; PERAL, B.; ARENAS, J. Elderly persons and Internet use. Social Science Computer Review, v. 31, n. 4, p. 389-403, 2013.

TOUDERT, D. La brecha digital en los contextos de marginación socioterritorial en localidades mexicanas: exploración y discusión. Comunicación $\mathbf{y}$ sociedad, n. 19, p. 153-180, 2013.

VAN-DEURSEN, A. J.; VAN-DIJK, J. A. The digital divide shifts to differences in usage. New Media \& Society, v. 16, n. 3, p. 507-526, maio 2014.

VAN-DEURSEN, A.; VAN-DIJK, J. Internet skills and the digital divide. New media \& society, v. 13, n. 6, p. 893-911, 2011. 